\title{
THE ANALYSIS OF LEARNING STRATEGY IN SPEAKING SKILL: A STUDY ON PEOPLE WITH DISABILITY
}

\author{
Muhammad Iqbal Adikusuma ${ }^{1}$, Fakhri Fikri ${ }^{2}$, Rasi Yugafiati ${ }^{3}$ \\ ${ }^{1}$ IKIP Siliwangi \\ ${ }^{2}$ IKIP Siliwangi \\ ${ }^{3}$ IKIP Siliwangi \\ ${ }^{1}$ iqbal.adikusuma@yahoo.com, ${ }^{2}$ fakhri.fikri12@gmail.com, ${ }^{3}$ tanya.rasiyugafiati@gmail.com
}

\begin{abstract}
People with disability have their chance to get the education as well as the other people. While they continue their study on higher level of education, they learn several subjects, included English. One of the skills should be mastered in learning English is speaking. Their speaking skill may different with the ordinary people who can see how the lecturers produce the utterances and watch the movies, etc. Thus, the people with disability have their own learning stategy to achieve the speaking skills. They use those learning strategies because they hope to master the speaking skills as good as the ordinary ones no matter what. The research method is descriptive qualitative. There are two participants in the research. They use application of screen reader to drill the vocabulary and pronounciation. Screen reader is one of the applications that help people with disability to master speaking skill. It can be downloaded in playstore. They learn speaking skill autodidactly. They also brave to practice their speaking skill with lecturers and classmate of English Department.
\end{abstract}

Keywords: people with disability, learning strategy, speaking skill

\section{INTRODUCTION}

The development of English as a global language strengthen its position as a lingua franca (Rahmawati \& Ertin, 2015). English is used in most countries in the world as a second language. It is used in a business, education, politics, and etc. English is consisted of 4 main skills. There are listening, speaking, reading, and writing skill. It is believed that speaking categorized as one of important skills. It is because people can communicate with speaking to another people. Basically, instrument of act can be classified in speaking (Clark \& Clark, 1977). In line with the statement above, Brown mentions that speaking is productive skill that can be directly and empirically observed (Brown, 2004). The important of speaking has been known by people across the world. In other hand, many people still have some difficulties in speaking English.

Many reseachers across the world do the research about the problems in speaking, one of them is Turk. He states that too many professional are nervous about speaking and worry that they do not speak well (Turk, 1985). It is believed that hesitation can be one of the problem in speaking English. Nervous also one of the big problem that distract people when speak English. It is about the problem in the people's mind. English speaking skill is used by some people to communicate. The blind persons as one of the disability people, all this time have a dissimilar education entrance from the normal people (Sunardi, Nugroho, \& Budiharjo, 2014). This matter caused by society perspective that blind persons have a condition that can not see or use their eyesight well in their activity (Nawawi, 2010). However, some of them with their limitation are there that study in normal school, the example is in IKIP SILIWANGI. In this research, the 
researcher would like to investigate their learning strategy in learning English speaking skill. Based on the background above, the researcher would like to do further research entitled The Analysis of Learning Strategy in Speaking Skill: A Study of People with Disability.

\section{People With Disability}

Disabilities cover blindness, paraplegia, deafness, diabetes, autism, epilepsy, depression, and HIV (Wasserman, David, Asch, Adrienne, Blustein, Jeffrey and Putnam, 2016). Based on Undang-Undang Number 19 Year 2011 about Pengesahan Hak-hak Penyandang disabilitas, person with disability (PWD) means person who get disable physically, mentally, intellectually, or sensorically in long term that impact his/her interaction in the environment based on the right (Undang-Undang No 19, 2011). People with disabilities physically can be categorized in several parts. One of them is blindness where people face difficulties in seeing and classified as blind and low vision (Reefani, 2013). In the Undang-undang No. 4 year 1997 about person with disability in point 1 of conversion explailns that every person with disability physically and/or mentality who face the obstacle for him/herself (Undang-Undang No 4, 1997).

\section{Learning Strategy}

In fact, some of universities can not allow people with disability to follow study program based on some reasons, such as incomplete facilities, even doubt of their capacity of learning (Sidiq, 2007). In the real situation, people with disability receive less attention related to the opportunities and facilities (Sholeh, 2015). It leads people with disability to find out proper learning strategies in studying speaking skill.

\section{METHOD}

This research is mainly descriptive qualitative. Descriptive research draws the collected data without any goals to get the general conclusion (Sugiyono, 2012). This study is conducted in IKIP Siliwangi Bandung. There are five participants in the research. This study employs some data collection techniques, using one questionnaire as instrument, classroom observation, interview, and document analysis as triangulation. The data analysis in this study is conducted over the course. All the data gained from the data collections are analyzed gradually. The data from questionnaires are transcribed and subsequently categorized, then interpreted to answer the research questions. The triangulations from interview, classroom observation, and document analysis are also interpreted descriptively.

\section{RESULTS AND DISCUSSION}

\section{Results}

The table below shows about the results of the research.

Table 1. The Result of the Research

\begin{tabular}{|c|c|c|c|c|c|c|c|}
\hline No & Name & $\begin{array}{l}\text { Opinion about } \\
\text { English }\end{array}$ & $\begin{array}{l}\text { The Importance of } \\
\text { Speaking Skill }\end{array}$ & $\begin{array}{c}\text { The Obstacles } \\
\text { in learning } \\
\text { Speaking Skill }\end{array}$ & $\begin{array}{c}\text { The Strategies in } \\
\text { Learning Speaking } \\
\text { Skill }\end{array}$ & $\begin{array}{c}\text { The } \\
\text { Effectiveness } \\
\text { of the } \\
\text { Strategies }\end{array}$ & $\begin{array}{l}\text { Self-service or } \\
\text { need the other's } \\
\text { help }\end{array}$ \\
\hline \multirow[t]{2}{*}{ S1 } & \multirow[t]{2}{*}{$\begin{array}{l}\text { Sigit Y. } \\
\text { (low } \\
\text { vision) }\end{array}$} & $\begin{array}{c}\text { International } \\
\text { language for } \\
\text { communicating with } \\
\text { foreigners }\end{array}$ & $\begin{array}{l}\text { Extremely importance. } \\
\text { English as a tool of } \\
\text { communication. }\end{array}$ & $\begin{array}{c}\text { Pronunciation, } \\
\text { written text and } \\
\text { spoken } \\
\text { language, } \\
\text { phonetics }\end{array}$ & $\begin{array}{l}\text { Using Screen Reader } \\
\text { application. Drilling } \\
\text { method. }\end{array}$ & $\begin{array}{c}\text { Effective. } \\
\text { Another } \\
\text { strategy is } \\
\text { getting partner } \\
\text { for practicing } \\
\text { speaking skill. }\end{array}$ & $\begin{array}{l}\text { Auto-didact, self- } \\
\text { taught }\end{array}$ \\
\hline & & $\begin{array}{l}\text { English as } \\
\text { international } \\
\text { language }\end{array}$ & $\begin{array}{l}\text { Extremely importance. } \\
\text { Speaking is one of } \\
\text { language skills for }\end{array}$ & & $\begin{array}{l}\text { Using Screen Reader } \\
\text { application. Drilling } \\
\text { method. Practicing }\end{array}$ & $\begin{array}{l}\text { Quite effective. } \\
\text { Wonted in }\end{array}$ & $\begin{array}{l}\text { Auto-didact, } \\
\text { practicing small }\end{array}$ \\
\hline
\end{tabular}




\begin{tabular}{|c|c|c|c|c|c|c|c|}
\hline S2 & $\begin{array}{c}\text { Annisa } \\
\text { Pratiwi } \\
\text { (low } \\
\text { vision) }\end{array}$ & & $\begin{array}{l}\text { communicating with } \\
\text { foreigners }\end{array}$ & $\begin{array}{c}\text { Vocabulary } \\
\text { mastery }\end{array}$ & $\begin{array}{l}\text { speaking skills with } \\
\text { partners. }\end{array}$ & $\begin{array}{c}\text { practicing } \\
\text { speaking skill. }\end{array}$ & $\begin{array}{l}\text { conversation with } \\
\text { friend. }\end{array}$ \\
\hline S3 & $\begin{array}{l}\text { Tubagus } \\
\text { Muhamm } \\
\text { ad } \\
\text { Abiem- } \\
20 \text { y.o } \\
\text { (low } \\
\text { vision) }\end{array}$ & $\begin{array}{l}\text { English as an } \\
\text { international } \\
\text { language. Used in } \\
\text { bussiness, food, and } \\
\text { many aspects. }\end{array}$ & $\begin{array}{l}\text { Speaking is used } \\
\text { directly while } \\
\text { communicating with } \\
\text { people. }\end{array}$ & $\begin{array}{c}\text { Self confidence, } \\
\text { English is used } \\
\text { by meaning, not } \\
\text { by translating } \\
\text { word to word. }\end{array}$ & $\begin{array}{l}\text { Adding vocabularies } \\
\text { by reading novel, } \\
\text { listen to the music, } \\
\text { and watching } \\
\text { English movies. } \\
\text { Don't speak } \\
\text { formally. Get the } \\
\text { meaning, don't really } \\
\text { stick to grammar. }\end{array}$ & $\begin{array}{c}\text { Effective. First } \\
\text { step, collect } \\
\text { vocabularies as } \\
\text { many as } \\
\text { possible by } \\
\text { using song, } \\
\text { movie or novel. } \\
\text { Next step is } \\
\text { using } \\
\text { conversation } \\
\text { with foreigner. }\end{array}$ & $\begin{array}{c}\text { Auto-didact, then } \\
\text { communicate with } \\
\text { others }\end{array}$ \\
\hline S4 & $\begin{array}{l}\text { Nenden } \\
\text { Sri } \\
\text { Agustina } \\
-19 \text { y.o } \\
\text { (low } \\
\text { vision) }\end{array}$ & $\begin{array}{c}\text { English as } \\
\text { international } \\
\text { language. English } \\
\text { helps people to } \\
\text { communicate while } \\
\text { go abroad. }\end{array}$ & $\begin{array}{l}\text { The most importance } \\
\text { language skill than the } \\
\text { others. }\end{array}$ & $\begin{array}{c}\text { Speak one } \\
\text { sentence in } \\
\text { rapidly } \\
\text { frequency. } \\
\text { Different } \\
\text { spoken } \\
\text { production such } \\
\text { as want to } \rightarrow \\
\text { wanna. } \\
\text { Different ways } \\
\text { of written text } \\
\text { and spoken } \\
\text { language. }\end{array}$ & $\begin{array}{l}\text { Using song lyrics. } \\
\text { Finding partners for } \\
\text { communicating in } \\
\text { English by using } \\
\text { chat or face to face. } \\
\text { Self talk. Repeating } \\
\text { the material that has } \\
\text { been studied }\end{array}$ & $\begin{array}{l}\text { Extremely } \\
\text { effective. Using } \\
\text { applications } \\
\text { sometimes are } \\
\text { error or unclear. }\end{array}$ & $\begin{array}{l}\text { Mostly Auto- } \\
\text { didact }\end{array}$ \\
\hline S5 & $\begin{array}{l}\text { Riko } \\
\text { Perwana } \\
\text { Saputra - } \\
21 \text { y.o } \\
\text { (low } \\
\text { vision) }\end{array}$ & $\begin{array}{c}\text { English as } \\
\text { international } \\
\text { language in } \\
\text { Globalization Era }\end{array}$ & $\begin{array}{l}\text { As importance as } \\
\text { listening, reading, dan } \\
\text { writting skills }\end{array}$ & Pronunciation & $\begin{array}{c}\text { Using application for } \\
\text { practicing } \\
\text { pronunciation as } \\
\text { well as native } \\
\text { speaker }\end{array}$ & $\begin{array}{l}\text { The using of the } \\
\text { application is } \\
\text { effective. } \\
\text { Moreover, if it } \\
\text { is applied by } \\
\text { praticing with } \\
\text { partners. }\end{array}$ & $\begin{array}{l}\text { For installing the } \\
\text { application, he } \\
\text { needs other's help. } \\
\text { For practicing, he } \\
\text { can do auto- } \\
\text { didactly. }\end{array}$ \\
\hline
\end{tabular}

\section{Discussion}

From the table 1 above, there are 5 participants in the research. The first question reveals the phenomenon of their paradigm about the importance of English. All of them say that English is important. It is because English categorized as one of international languages. The S1 and S2 adds the information that English is used for communicating with foreigners because English is an international language. While S3 says that English is used in bussiness, food, and many aspects. S4 also says that English helps people to communicate while go abroad. S5 explains that English is applied as international language in globalization era. All of these statements is reinforced by (Lauder, 2008), the current prestige of English as an international or global language is supported by its widespread use in a range of fields such as politics, diplomacy, international trade and industry, commerce, science and technology, education, the media, information technology, and popular culture. Hence, English language is influencing many aspects of life. Whether it is in business, food, education, etc. Their awareness of the importance of English could be motivation to improve their skill in foreign language.

Based on the table 1 above, five participants give their opinion on the importance of speaking skill. S1 and S2 agree that English is extremely importance. S1 says that English as a tool of communication. Thus, S2 argues that speaking becomes one of language skills for communicating with foreigners. S3 explain that speaking is used directly while communicating with people. Moreover, S4 explains that speaking can be categorized as the most importance language skill than the others. Meanwhile S5 againsts the S4's explanation by saying that speaking skill can be categorized as importance as listening, reading, and writting skills. These statements is strengthed by (Baidawi, 2016), Speaking is one of the important skills to be learnt and grasped. It is because the participants want to use English as a mean for more global communication. Thus, speaking skill could has become the main point in mastering English and as equal as another skills. 
From the table 1 above, there are 5 participants response on the obstacles in learning speaking skill. S1 and S5 have same paradigm that the obstacle in speaking skill is pronounciation. S1 and S4 agree that the difficulties also pop up in written text and spoken language. S1 then finds the obstacle on phonetics while applying speaking skill. S2 explains that the problem comes from the vocabulary mastery. S3 has different difficulty. S3 finds the problem on self confidence. It leads S3 to speak in English by meaning, not by translating word to word. S4 adds the opinion that the problem on speaking skill is saying utterances in rapidly frequency. S4 also confuses with spoken production which is different from written test, such as "want to" produces as "wanna". The obstacles that the participants faced in learning speaking skills above are the same as the obstacles found by (Muamaroh, 2009), Muamaroh finds that the most obstacles faced by the student in learning speaking are lack of vocabulary, weak in grammar, difficulty in pronounciation, and also in affective aspects like anxiety, fear, shame, and lack of self-confident. No surprised that the participants got the difficulty in learning speaking skill, not only them as disable person, but also normal people have the same difficulty to learn speaking skill.

Based on the table 1 above, there are 5 participants response on the strategies in learning speaking skill. S1 and S2 use Screen Reader application and drilling method. S2 also practice speaking skills with partners. S3 adds vocabularies by reading novel, listens to the music, and watches English movies. S3 suggests to not to speak formally, get the meaning, and not really stick to grammar. S4 uses song lyrics as her strategy in learning speaking skill. S4 also finds partners for communicating in English by using chat or face to face. S4 adds her efforts by doing self-talk. S4 then repeats the material that has been studied. S5 uses application for practicing pronunciation as well as native speaker. S1 and S2 have the same strategy, that is using screen reader that can be categorized as e-learning. As stated by Abbad, Morris, \& de Nahlik, (2009), e-learning means any knowledge that is qualified electronically. For sure, it will help the participants to study, especially language learning.

Moreover, based on the table 1 above, there are 5 participants response on the effectiveness of the strategies. S1, S3, and S5 say that their strategies are effective. S2 says her strategies are quite effective. S4 says her strategies are Extremely effective. Beside on doing the strategies in learning speaking skill, S1 applies another strategy by getting partner for practicing speaking skill. S2 is wonted in practicing speaking skill. S3 has two steps: First step, collect vocabularies as many as possible by using song, movie or novel. Next step is using conversation with foreigner. S4 says her strategies are extremely effective. It is because the using of applications sometimes are error or unclear. S5 applies the strategies by practicing with partners. Almost all of the participants response a positive attitude towards all of the strategies used. The use of various learning strategies is the positive action because as stated by Vandergrift, L., Goh, C. C. M., Mareschal, C., \& Tafaghodtari, (2006), high grades of strategic alertness helps language learners act better at handling and keeping new information, find the best ways to practice and support what they have learned. Being strategic learners could help the participants to learn faster and easier rather than the rest of them.

From the table 1 above, there are 5 participants response on Self-service or need the other's help. S1 prefers auto-didact and self-taught. S2 learns auto-didact, practicing small conversation with friend. S3 prefers auto-didact, then communicates with others. S4 studies speaking skill by mostly auto-didact. S5 thinks that for installing the application, he needs other's help. For practicing, he can do auto-didactly.From the third until fifth paraghraph, the participants' strategies in improving their speaking skill are like encourage their self to learn indep endently, using some media such as screen reader application, using song lyrics, and 
novel in improving speaking skill show that they use self-directed learning approach. According to Knowles (1975), self-directed learning is a process in which individuals take the initiative, with or without the help of others, in diagnosing their learning needs, articulating learning goals, classifying human and material assets for learning, choosing and implementing appropriate learning strategies, and evaluating learning outcomes (Scott, 2006). The initiative and motivation for self-directed learning, using a variety of facilities outside the classroom, and using a variety of learning strategies like drilling metode, self-talk, and using screen reader aplication will be a valuable capital to cover the shortage the material gained in the classroom, the self-directed learning will also make them able to surpass their classmates who have no limitations, but lack of initiative and motivation to self-directed learning.

\section{CONCLUSION}

From the discussion and result above, we can conclude that, first about phenomenon of their paradigm about the importance of English. All of them said that English is really an important language because it affect many aspects in many ways, especially because English is an international language, it will affect business, food, and help people to go abroad and communicate with other people. The second aspect is about the importance of speaking in English. They agreed that speaking is an important skill because speaking itself is a tool of communication to communicate with foreigner. Speaking is used directly when communicating with people. Some of them said that speaking is the most important skill but some other said that speaking skill importance is as equal as another skill (listening, reading, writing). The third aspect is the obstacle in learning speaking skill. They speculate that the obstacle in speaking skill is about vocabulary mastery, pronounciation, and phonetic, so it is quite difficult for them to say some utterance. Some of them also said that mentality problem like confidence also affect their speaking ability. The fourth aspect is strategies in learning speaking skill. Most of them is learning English with the help of some application named "screen reader". They also learn with reading novel, listen to music, and watch movie. Some of them said for not to speak formally, just get the meaning of it. They remembering the vocabulary and drill it or repeat it then do a small conversation with some partner. The last aspect is the effectiveness of their method in learning speaking. Most of them said that their method are really efective. Some of them said that to learn speaking skill they have to collect vocabularies as many as possible, then use it in conversation. Most of them learn with auto-didact then do a conversation with the other. For further research, researchers suggest that another researcher should do the deeper research about the use of application or cooperative learning or do research from the another skills instead of speaking skills.

\section{ACKNOWLEDGMENTS}

The source of any financial support received for the work being published is independent.

\section{REFERENCES}

Abbad, M. M., Morris, D., \& De Nahlik, C. (2009). Looking Under The Bonnet: Factors Affecting Student Adoption Of E-Learning Systems In Jordan. International Review Of Research In Open And Distance Learning, 10(2), 1-25. Https://Doi.Org/Dx.Doi.Org/10.19173/Irrodl.V10i2.596

Baidawi, A. (2016). Using Visual Media In Teaching Speaking. Okara Journal Of Languages And Literature, 1, 54-65.

Brown, H. D. (2004). Langauge Assessment Principle And Classroom Practices. New York: 


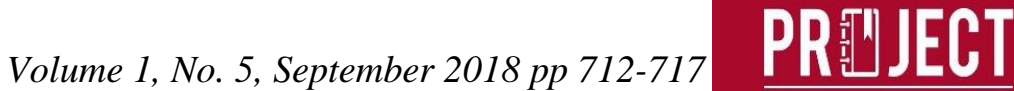

Person Education.

Clark, H. H., \& Clark, E. V. (1977). Psychology And Language: An Introduction To Psycholinguistics. Language. New York: Harcourt Brace Jovanovich.

Lauder, A. (2008). The Status And Function Of English In Indonesia: A Review Of Key Factors. Makara, Social Humaniora, 12(1), 9-20. Retrieved From Http://Journal.Ui.Ac.Id/Index.Php/Humanities/Article/Viewfile/128/124

Muamaroh. (2009). Oral English Proficiency: Obstacles And Solution For University Students On Muhammadiyah University Of Surakarta Muamaroh. Kajian Linguistik Dan Sastra, 21(1), 1-10.

Nawawi, A. (2010). Pendidikan Inklusi Bagi Anak Low Vision. Bandung: Upi Bandung.

Rahmawati, Y., \& Ertin, E. (2015). Developing Assessment For Speaking. Ijee (Indonesian Journal Of English Education), 1(2). Https://Doi.Org/10.15408/Ijee.V1i2.1345

Reefani, N. K. (2013). Panduan Anak Berkebutuhan Khusus. Yogyakarta: Imperium.

Scott, K. W. (2006). International Journal Of Self-Directed Learning, 3(2).

Sholeh, A. (2015). Islam Dan Penyandang Disabilitas: Telaah Hak Aksesibilitas Penyandang Disabilitas Dalam Sistem Pendidikan Di Indonesia. Palastren, 8(2), 293-320. Retrieved From Http://Download.Portalgaruda.Org/Article.Php?Article=401058\&Val=6786\&Title=Isla m Dan Penyandang Disabilitas : Telaah Hak Aksesibilitas Penyandang Disabilitas Dalam Sistem Pendidikan Di Indonesia

Sidiq, D. M. (2007). Mahasiswa Difabel Di Perguruan Tinggi, In Sekar Ayu Aryani (Ed.) Desain Pembelajaran Sensitif Difabel. Yogyakarta: lis Pps Uin.

Sugiyono. (2012). Memahami Penelitian Kualitatif. Bandung: Cv Alfabet.

Sunardi, Nugroho, \& Budiharjo. (2014). Media Pembelajaran Sintaksis Bahasa Inggris Bagi Mahasiswa Tunanetra. In Prosiding Seminar Nasional Teknologi Informasi Dan Komunikasi Terapan 2014. Semarang: Lembaga Penelitian Dan Pengabdian Masyarakat Universitas Dian Nuswantoro.

Turk, C. (1985). Effective Speaking : Communicating In Speech. London: E. \& F.N. Spon. Undang-Undang No 19, Pub. L. No. 19 (2011). Indonesia.

Undang-Undang No 4, Pub. L. No. Undang-Undang No 4 (1997). Indonesia.

Vandergrift, L., Goh, C. C. M., Mareschal, C., \& Tafaghodtari, M. H. (2006). The Metacognitive Awareness Listening Questionnaire: Development And Validation. A Journal Of Research In Language Studies, 56(3), 431-462.

Wasserman, David, Asch, Adrienne, Blustein, Jeffrey And Putnam, D. (2016). Disability: Definitions, Models, Experience. In The Stanford Encyclopedia Of Philosophy (Summer 2016 Edition) (Summer 201). Retrieved From Https://Plato.Stanford.Edu/Entries/Disability/ 